\title{
Diversity of Rhizoctonia spp. Causing Foliar Blight on Brachiaria in Colombia and Evaluation of Brachiaria Genotypes for Foliar Blight Resistance
}

Elizabeth Alvarez, Michael Latorre, and Ximena Bonilla, Plant Pathology, Guillermo Sotelo, Plant Entomology, and John W. Miles, Plant Breeding, Tropical Forages Program, International Center for Tropical Agriculture, A.A. 6713, Cali, Colombia

\begin{abstract}
Alvarez, E., Latorre, M., Bonilla, X., Sotelo, G., and Miles, J. W. 2013. Diversity of Rhizoctonia spp. causing foliar blight on Brachiaria in Colombia and evaluation of Brachiaria genotypes for foliar blight resistance. Plant Dis. 97:772-779.

Up to $50 \%$ of Brachiaria production in the tropics is affected by foliar blight caused by Rhizoctonia spp. Monothallic isolates of Rhizoctonia $(n=147)$ were cultured from different Brachiaria genotypes in Colombia and morphologically characterized and evaluated in pathogenicity trials in the greenhouse. Based on restriction fragment length polymorphism of the internal transcribed spacer region, 101 of the isolates were identified as Rhizoctonia solani anastomosis group (AG)-1 IA and were multinucleated, with high growth rate, brown mycelium, and high virulence; and 46 isolates were identified as Rhizoctonia sp. AG$\mathrm{D}$ and were binucleated, with low growth rate, white mycelium, and lower virulence on the Brachiaria genotypes tested. The Rhizoctonia

isolates also showed variation according to geographic origin, with $R$. solani AG-1 IA prevalent in warm lowland areas and Rhizoctonia sp. AG-D occurring in cooler areas. Ten Brachiaria genotypes were challenged with different Rhizoctonia isolates and resistant reactions were seen in three of these genotypes, including Brachiaria hybrid (International Center for Tropical Agriculture [CIAT] 36062), Brachiaria brizantha 'Marandú' (CIAT 6294), and Brachiaria hybrid 'Mulato II' (CIAT 36087). These results will contribute to a greater understanding of the interaction of diverse Rhizoctonia isolates on different Brachiaria genotypes, supporting improvement of Brachiaria spp. for disease resistance.
\end{abstract}

The genus Brachiaria (Trin.) Griseb. belongs to the Poaceae family and comprises about 100 species, some of which are economically valuable as tropical forage grasses sown for pasture (17). The genus is pan-tropical and has its center of diversity in Africa $(19,20)$. Several species are commonly used in lowland agro-ecosystems in the humid and subhumid tropics, especially in South America, and provide an important feed source for ruminant livestock (25). Perennial species of the genus such as Brachiaria decumbens, $B$. humidicola, and B. brizantha have achieved significant economic importance in these cropping systems which, in many cases, show pronounced soil acidity (17). These ecosystems occupy about $50 \%$ of Brazil; $60 \%$ of the area encompassed by Bolivia, Peru, and Ecuador; $40 \%$ of Mexico; and significant areas in other countries of the region (17). In the only study to address the economic impact of the adoption of new genotypes of Brachiaria in cropping systems of the north coast and the eastern plains of Colombia, the tropics of Mexico, and Central American countries, the impact was estimated in 2003 at U.S.\$4,166 million, of which $54 \%$ was estimated to be generated in the beef market and the rest in dairy. Most of the benefits were considered to be concentrated in Mexico, with U.S.\$2,831 million (68\%), followed by Colombia, U.S.\$960 million (23\%), and Central America, U.S.\$363 million (9\%) (21).

Cultivation of Brachiaria spp. is impacted by foliar blight, a destructive disease caused by pathogens in the fungal genus Rhizoctonia, which attack most Brachiaria cultivars when relative humidity and temperatures are high, conditions that favor the development of disease (17). Rhizoctonia pathogens occur throughout the world, causing severe damage on a broad range of crops

Corresponding author: E. Alvarez, E-mail: e.alvarez@cgiar.org

GenBank accession numbers JQ613574, JQ613575, JQ613576, JQ613577, JQ613578, JQ613579, and JQ613580.

Accepted for publication 4 January 2013.

http://dx.doi.org/10.1094/PDIS-04-12-0380-RE

(C) 2013 The American Phytopathological Society and ornamental plants as well as Brachiaria spp. $(8,18,30)$. In the eastern plains of Colombia, the incidence and severity of Rhizoctonia foliar blight has become important, leading to losses in yield (15). In order to better understand the diversity of Rhizoctonia spp. involved in foliar blight in Colombia, Rhizoctonia isolates causing leaf blight on Brachiaria cultivars were characterized using in vitro morphology, nuclear condition, and restriction fragment length polymorphism (RFLP). After assessing the genetic diversity of Rhizoctonia isolates collected in the field, a search was initiated for host-plant resistance to this pathogen in commercial Brachiaria spp. We also compared the variation in virulence of isolate-host genotype interactions that may affect screening for Rhizoctonia foliar blight resistance.

\section{Materials and Methods}

Rhizoctonia isolates. Infected plant samples $(n=418)$ from different Brachiaria genotypes with typical symptoms of foliar blight were collected in the Colombian departments (political divisions) of Cauca, Meta, Casanare, Córdoba, and Caquetá (Fig. 1; Table 1) Initial symptoms appeared as water-soaked lesions, then darkened and turned light brown. Small fragments $\left(5 \mathrm{~mm}^{2}\right)$ of diseased tissue were washed in $70 \%$ alcohol for $1 \mathrm{~min}$ and $1 \%$ sodium hypochlorite for $1 \mathrm{~min}$, and rinsed with sterilized distilled water for 1 min. These fragments were placed on potato dextrose agar (PDA) medium (39 $\mathrm{g}$ of PDA per liter of distilled water) supplemented with amoxicillin at $300 \mathrm{mg} / \mathrm{liter}$ and incubated $24 \mathrm{~h}$ at $30^{\circ} \mathrm{C}$. Mycelium that grew on the surface of the tissue was transferred to fresh PDA medium and incubated for 48 to $72 \mathrm{~h}$ at $30^{\circ} \mathrm{C}$. Rhizoctonia isolates were identified through macroscopic and microscopic observations. Characteristics such as color of the culture medium, hyphal branches that formed right angles, constriction at the base of the branching, and septa in both branches of the angle were assessed (8). Isolates identified as Rhizoctonia spp. were transferred to new PDA plates for growth.

Pure isolates were cultured on water agar (15 g of agar per liter of distilled water). Hyphal tips viewed with a stereoscope were transferred to PDA plates containing amoxicillin at $300 \mathrm{mg} / \mathrm{liter}$ and incubated in the dark at $30^{\circ} \mathrm{C}$ for 48 to $96 \mathrm{~h}$. These monothallic cultures were stored on filter paper in the dark at $-20^{\circ} \mathrm{C}$, according to the methodology described by Aricapa and Correa (2). 
Morphological characterization of Rhizoctonia isolates. The monothallic Rhizoctonia cultures were characterized based on their color, nuclear condition, growth rate, and production of sclerotia. Nuclear condition was determined by staining with safranin $\mathrm{O}$ and $\mathrm{KOH} \mathrm{3 \% ,} \mathrm{according} \mathrm{to} \mathrm{Bandoni} \mathrm{(3).} \mathrm{Data} \mathrm{from} 20$ individual cells per isolate were averaged to estimate the number of nuclei per cell. To determine the growth rate, isolates were cultured in $90-\mathrm{mm}$ petri dishes containing PDA in a randomized complete block design with three replications. The experiment was repeated twice. Disks, $4 \mathrm{~mm}$ in diameter, were cut from the edge of a 5-day-old colony and placed in the center of petri dishes with the mycelium in direct contact with the PDA medium. The isolates were incubated at $28 \pm 1{ }^{\circ} \mathrm{C}$ for 8 days and radial growth was measured daily. To calculate the growth rate of isolates in millimeters per day, the following formula was used (29): $V=\left(X_{\mathrm{f}}-X_{\mathrm{i}}\right) /\left(t_{2}-t_{1}\right)$, where $V$ is the growth rate, $X_{\mathrm{f}}$ is the mean final growth (diameter in $\mathrm{mm}$ ), $X_{\mathrm{i}}$ is the mean initial growth (diameter in $\mathrm{mm}$ ), $t_{2}$ is end time in days, and $t_{1}$ is the initial time. Analysis of variance was carried out with the Statistical Analysis System (SAS) program, version 9.0 (22), and the Ryan-Einot-Gabriel-Welsch Multiple Range Test was then used to separate groups of isolates that differed in growth rate. Qualitative traits, such as color and sclerotium production, were also recorded.

RFLP and sequence analyses of the internal transcribed spacer region. Total genomic DNA was extracted from a selection of isolates chosen to represent variation in geographic origin, growth rate, color, host, nuclear condition, and virulence. Isolates were grown for 5 days in potato dextrose broth (PDB). Mycelium was collected by vacuum filtration and washed with sterile distilled water, then freeze dried and ground to a fine powder under liquid nitrogen (1). Universal primers intergenic transcribed spacer region internal transcribed spacer (ITS) 1 and ITS 4 (29) were used to amplify the ITS region of ribosomal DNA (rDNA). Each 30- $\mu 1$ polymerase chain reaction (PCR) contained $0.3 \mu$ of each primer

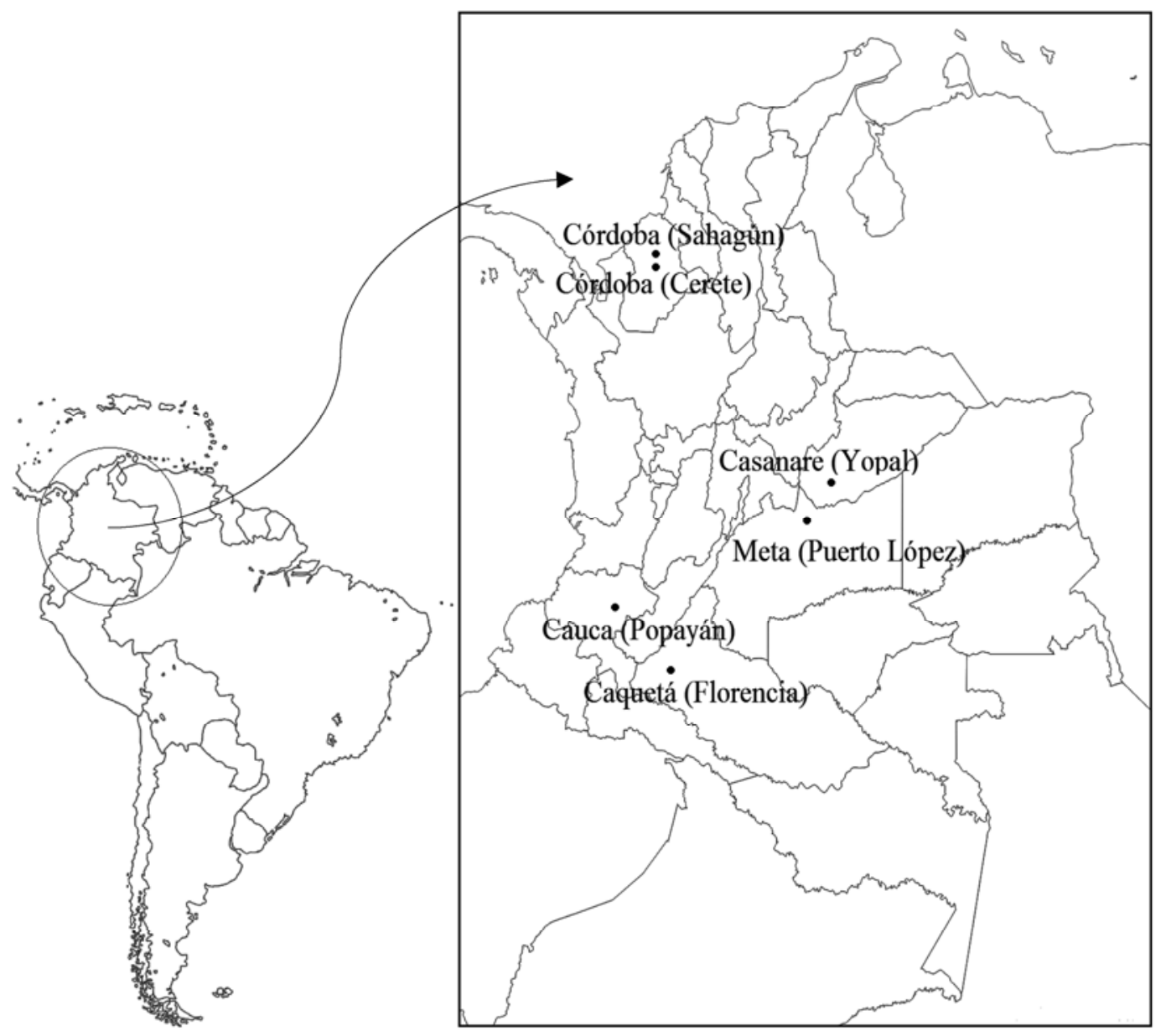

Fig. 1. Map of Colombia, showing approximate locations of collection sites.

Table 1. Collection sites with respective latitude, longitude, elevation, precipitation, mean annual temperature, and relative humidity ${ }^{\mathrm{a}}$

\begin{tabular}{|c|c|c|c|c|c|c|}
\hline Collection sites & Latitude & Longitude & $\begin{array}{c}\text { Elevation } \\
\text { (masl) }\end{array}$ & $\begin{array}{c}\text { Precip } \\
(\mathbf{m m})\end{array}$ & $\begin{array}{c}\text { Temp } \\
\left({ }^{\circ} \mathbf{C}\right)\end{array}$ & $\begin{array}{l}\text { RH } \\
(\%)\end{array}$ \\
\hline CES = CIAT Experiment Station, Popayán & $2^{\circ} 26^{\prime} 36^{\prime \prime}$ & $76^{\circ} 37^{\prime} 17^{\prime \prime}$ & 1,760 & 1,941 & $18-20$ & 77 \\
\hline DF $=$ The Dacha Farm, Puerto López, Meta & $4^{\circ} 5^{\prime} 6^{\prime \prime}$ & $72^{\circ} 57^{\prime} 19^{\prime \prime}$ & 200 & 2,500 & $26-28$ & 77 \\
\hline MF = Santana Farm, Puerto López, Meta & $4^{\circ} 5^{\prime} 6^{\prime \prime}$ & $72^{\circ} 57^{\prime} 19^{\prime \prime}$ & 200 & 2,500 & $26-28$ & 77 \\
\hline SCF $=$ Santa Clara Farm, Remolino, Puerto López, Meta & $4^{\circ} 5^{\prime} 6^{\prime \prime}$ & $72^{\circ} 57^{\prime} 19^{\prime \prime}$ & 200 & 2,500 & $26-28$ & 77 \\
\hline LIF = "La ilusión" Farm, Morichal, Yopal, Casanare & $5^{\circ} 21^{\prime} 6^{\prime \prime}$ & $72^{\circ} 24^{\prime} 11^{\prime \prime}$ & 350 & 2,324 & $26-28$ & 80 \\
\hline VCC = "Villa María" Farm, Sahagún, Córdoba & $8^{\circ} 57^{\prime} 12^{\prime \prime}$ & $75^{\circ} 27^{\prime} 13^{\prime \prime}$ & 75 & 1,600 & $28-30$ & 86 \\
\hline $\mathrm{ACC}=$ "Altamonte" Farm, Cereté, Córdoba & $8^{\circ} 57^{\prime} 12^{\prime \prime}$ & $75^{\circ} 27^{\prime} 13^{\prime \prime}$ & 75 & 1,600 & $28-30$ & 86 \\
\hline TCC = "Turipaná" Farm, Cereté, Córdoba & $8^{\circ} 53^{\prime} 8^{\prime \prime}$ & $75^{\circ} 47^{\prime} 48^{\prime \prime}$ & 12 & 1,646 & $28-30$ & 80 \\
\hline MFC = "Macagual" Farm, Florencia, Caquetá & $1^{\circ} 37^{\prime} 3^{\prime \prime}$ & $75^{\circ} 37^{\prime} 3^{\prime \prime}$ & 242 & 3,840 & $25-28$ & 86 \\
\hline
\end{tabular}

${ }^{a}$ Elevation in meters above sea level (masl), Precip = annual precipitation, Temp = annual average temperature, and $\mathrm{RH}=$ relative humidity. 
at a concentration of $50 \mu \mathrm{M}(0.5 \mu \mathrm{l}) ; 0.25 \mu \mathrm{l}$ of Taq polymerase at 5 $\mathrm{U} / \mu \mathrm{l}(0.04 \mathrm{U} / \mu \mathrm{l}) ; 2.4 \mu \mathrm{l}$ of the dinucleotides dATP, dCTP, dGTP, and dTTP at a concentration of $2.5 \mathrm{mM}$ each $(0.2 \mathrm{mM}) ; 6 \mu \mathrm{l}$ of buffer $(5 \times ; 10 \mathrm{mM}$ Tris- $\mathrm{HCl}$ [pH 8.3], $50 \mathrm{mM} \mathrm{KCl}$, and $15 \mathrm{mM}$ $\left.\mathrm{MgCl}_{2}\right)(2 \times)$; and $1.2 \mu \mathrm{l}$ of fungal DNA at a concentration of 5 $\mathrm{ng} / \mu \mathrm{l}(0.2 \mathrm{ng} / \mu \mathrm{l})$. The reactions were carried out in a thermal cycler (PTC-100 Peltier Thermal Cycler; MJ Research, Inc.), and amplification conditions included denaturation at $94^{\circ} \mathrm{C}$ for $3 \mathrm{~min}$; followed by 30 cycles of denaturation at $94^{\circ} \mathrm{C}$ for $1 \mathrm{~min}$, annealing at $59^{\circ} \mathrm{C}$ for $1 \mathrm{~min}$, an extension of $72^{\circ} \mathrm{C}$ for $2 \mathrm{~min}$; with a final extension at $72^{\circ} \mathrm{C}$ for $3 \mathrm{~min}$. The PCR products were resolved using electrophoresis in $1 \times$ Tris base, acetic acid, and EDTA (TAE) buffer on $1.2 \%$ agarose gels visualized with GelRed (nucleic acid gel stain, 10,000×; Life Technologies (India), Pvt. Ltd.). The amplified products were digested with restriction enzymes EcoRI, $M b o \mathrm{I}, A l u \mathrm{I}$, and $T a q \mathrm{I}$ according to the manufacturer's directions (New England Biolabs). Electrophoresis was carried out in 3\% agarose with $1 \times$ TAE buffer. The DNA bands were stained with GelRed (nucleic acid gel stain, 10,000×) and visualized under UV light. To determine molecular weights of PCR products, we used a 50-bp DNA ladder (New England BioLabs, Inc.). Isolate A36061 of anastomosis group (AG)-1 was included for comparisons (15). A similarity analysis was carried out with the binary matrix data obtained from restriction bands generated by the PCR-RFLP technique. Comparisons were carried out on the basis of the presence or absence of each band. A dendrogram was then made using the unweighted pairwise group method with arithmetic average using a Dice coefficient (13). The amplified PCR products (rDNA of the ITS regions) were sequenced and the sequences subjected to a BLAST search to determine their similarity to sequences in GenBank. Sequencing was carried out in the laboratories of the Iowa State University DNA Facility (Molecular Biology Building). Data sequences obtained were examined with ChromasPro software and the database of GenBank (National Center for Biotechnology Information).

Pathogenicity tests. The aggressiveness of all isolates on a single host genotype (Brachiaria hybrid 'Mulato', International Center for Tropical Agriculture [CIAT] 36061) was compared in a fivereplicate, randomized complete block experiment. The experiment was repeated twice. Tillers of Mulato, 20 to $25 \mathrm{~cm}$ tall, were detached from the mother plant and their roots and leaves were trimmed, with exception of the flag leaf. The vegetative material was immersed for $5 \mathrm{~min}$ in a $1 \%$ solution of sodium hypochlorite in distilled water to reduce contamination. The tillers were planted individually in PVC tubes, $5.3 \mathrm{~cm}$ wide by $6.5 \mathrm{~cm}$ deep, containing $36 \mathrm{~g}$ of sterilized soil (nursery mixture soil, soil, and sand in a 4:1:1 ratio) (5). Assays were conducted on 40-day-old plants which were $25 \mathrm{~cm}$ tall.

To prepare the inoculum, the individual fungal isolates were grown for 8 days on PDA medium supplemented with amoxicillin (300 mg/liter). A 4-mm disk of mycelium was placed at the point of union between the stem and the leaf blade of the lower (older) two leaves of each plant. Individual inoculated plants (experimental units) were incubated under greenhouse conditions at $28^{\circ} \mathrm{C}$. The aboveground portion of each plant was enclosed in a $600-\mathrm{ml}$, clear plastic drinking water bottle as a microchamber to create conditions of high relative humidity (80 to 100\%) and also physically isolate each individual plant so as to prevent leaf contact between adjacent plants $(5,14,24)$. Details of the microchamber are described by Cardona et al. (6), modified here by reducing the size of the bottle and number of ventilation holes (from 250 to 20).

Disease severity was evaluated using the Horsfall-Barratt scale, a 10-point severity scale to estimate visually the percentage of affected plant tissue (12). Symptoms scored were water-soaked lesions, darkened lesions, and light-brown lesions (7). The rating scale was based on percentage of tissue with visible symptoms: 0 to $3 \%$ (grade 1), 3.1 to $6 \%$ (grade 2), 6.1 to $12 \%$ (grade 3 ), 12.1 to $25 \%$ (grade 4), 25.1 to $50 \%$ (grade 5), 50.1 to $75 \%$ (grade 6), 75.1 to $88 \%$ (grade 7 ), 88.1 to $94 \%$ (grade 8 ), 94.1 to $97 \%$ (grade 9), and 97.1 to $100 \%$ (grade 10). Symptoms were evaluated every 3 days for 18 days following inoculation. The surface area of the plant (leaves and stems) was measured and compared with lesion area to determine the percent of infection.

Data on disease severity were used to calculate the area under the disease progress curve (AUDPC) as follows:

$$
\mathrm{AUDPC}=\sum_{i=1}^{n}\left(\frac{X_{i}+X_{i-1}}{2}\right)\left(t_{i}-t_{i-1}\right)
$$

where $X_{i}=$ severity of disease in the $i$ th evaluation $\left(X_{0}=0\right), t_{i}=$ time in days from inoculation to the $i$ th evaluation $\left(t_{0}=0\right)$, and $n=$ number of evaluations.

Values obtained for each experimental unit (plant) were submitted to an analysis of variance to assess differences among the fungal isolates. The Ryan-Einot-Gabriel-Welsch Multiple Range Test was then used to separate groups of isolates that differed in disease severity. For statistical analysis, AUDPC data were transformed using the natural logarithm function to meet the assumptions of normality and homogeneity of variance (Table 2). A Levene test detected heterogeneity of variances (F:2.13, $P>0.0001)$.

Virulence study. The virulence of select Rhizoctonia isolates was evaluated by inoculating 10 Brachiaria genotypes, each with 10 different fungal isolates plus a control (Tables 3 and 4). Nine of the isolates were selected from the 147 isolates collected in the present study. Isolates were chosen based on geographic origin, growth rate, color, host, nuclear condition, and virulence. One isolate, A-36061, was collected earlier and used in a CIAT breeding program to assess Brachiaria resistance to Rhizoctonia foliar blight (7). A split-plot experimental design was used, where isolates were assigned to main plots and host genotypes to the subplots. Each isolate-genotype combination was replicated five times for a total of 550 subplot experimental units (plants). The experi-

Table 2. Origin, pathogenicity, growth rate, nuclear condition, and color of Rhizoctonia isolates used in this study

\begin{tabular}{|c|c|c|}
\hline \multirow[b]{2}{*}{ Variables } & \multicolumn{2}{|r|}{ Species (number of isolates) ${ }^{\mathbf{a}}$} \\
\hline & Rhizoctonia sp. (46 isolates) & Rhizoctonia solani $(100$ isolates + A36061) \\
\hline Source & $\begin{array}{l}\text { Brachiaria brizantha, } B \text {. decumbens, } \\
\text { B. jubata, and B. platynota }\end{array}$ & $\begin{array}{l}\text { 'Mulato II', ‘Toledo', B. brizantha, B. decumbens, 'Mulato', B. mutica, Hibiscus } \\
\text { cannabinus; sorghum and sugarcane }\end{array}$ \\
\hline Origin & CES (46) & $\begin{array}{l}\mathrm{DF}(11), \operatorname{MF}(5), \operatorname{SCF}(5), \operatorname{LIF}(10), \mathrm{CC}(1), \operatorname{VCC}(12), \operatorname{ACC}(8), \mathrm{TCC} F S 1 \text { (3), TCC FS2 } \\
\text { (16), TCC FS3 (5), MFC FS1 (5), MFC FS2 (16), MFC FS3 (3) }\end{array}$ \\
\hline $\mathrm{AUDPC}^{\mathrm{b}}$ & $0.94-1.40$ & $0.48-2.50$ \\
\hline $\mathrm{GR}^{\mathrm{c}}$ & $12.18-17.50$ & $22.00-74.00$ \\
\hline Nuclear condition & Binucleate & Multinucleate \\
\hline Color & White & Brown \\
\hline
\end{tabular}

a CES = CIAT Experiment Station-Popayán; DF = The Dacha Farm, Puerto López, Meta; MF = Montana Farm, Puerto López, Meta; SCF = Santa Clara Farm, Remolino, Puerto López, Meta; LIF = "La Ilusión" Farm, Morichal Village District, Yopal, Casanare; CC = CIAT-Cali; VCC = "Villa Maria" Farm, Sahagún, Córdoba; ACC = "Altamonte" Farm, Sahagún, Córdoba; TCC = "Turipana" Farm, Cereté, Córdoba; MFC ="Macagual" Farm, Florencia, Caquetá; FS = field site. Number in parentheses shows how many isolates of each group were obtained at each location.

${ }^{\mathrm{b}}$ Area under the disease progress curve.

${ }^{\mathrm{c}}$ Growth rate (mm/day). 
ment was conducted twice, with a single host plant substitution in the second experiment (Table 3 ).

Host plants were propagated vegetatively and inoculated using the same methodology described above. The inoculated plants were evaluated every 3 days for 15 to 18 days to record disease progress. A visual scale of 0 to 5 was used following Cardona (5). A score of 0 signified no disease, 1 corresponded to 0.1 to $0.9 \%$ of the foliar area infected, $1.5=1$ to $11.9 \%$ infection, $2=12$ to $24.9 \%$ infection, $2.5=25$ to $36.9 \%$ infection, $3=37$ to $49.9 \%$ infection, $3.5=50$ to $61.9 \%$ infection, $4=62$ to $86.9 \%$ infection, $4.5=87$ to $99.9 \%$ infection, and $5=100 \%$ infection. Reliability of the methodology was determined previously $(4,5)$. For both trials, the same isolates (Table 4) and the same Brachiaria host genotypes (Table 3 ) were used, except that, for trial 2, genotype CIAT 16888 ( $B$. humidicola) was replaced by genotype CIAT 26110 (B. brizantha 'Toledo'). The behavior of the susceptible (RZ05NO/3333 and RZ05NO/3394) or resistant (CIAT 16320) controls of the two trials

Table 3. Host plants used to determine relative virulence of Rhizoctonia isolates analyzed in this study

\begin{tabular}{ll}
\hline Host plants & CIAT number or clone ${ }^{\mathbf{a}}$ \\
\hline Brachiaria hybrid 'Mulato' & CIAT 36061 \\
Brachiaria hybrid 'Mulato II' & CIAT 36087 \\
B. decumbens 'Basilisk & CIAT 606 \\
B. brizantha & CIAT 16320 \\
B. brizantha 'Marandú' & CIAT 6294 \\
B. ruziziensis & Clone $44-02$ \\
Brachiaria hybrid & CIAT 36062 \\
Brachiaria hybrid & Clone RZ05/3394 \\
Brachiaria hybrid & Clone RZ05/3333 \\
B. humidicola & CIAT 16888 \\
\hline
\end{tabular}

${ }^{a}$ CIAT = International Center for Tropical Agriculture.

' Replaced by B. brizantha 'Toledo' (CIAT 26110) in the second experiment. allowed comparisons of severity levels in the evaluated genotypes, ensuring that trial results were consistent.

The data analysis for the virulence assessments was generated using the SAS software, version 9, of the SAS System for Unix (22), using its MIXED procedure and REML estimation method (which calculates the errors adjusted to all comparisons).

\section{Results}

Rhizoctonia isolates. Plant tissue samples exhibiting foliar blight symptoms consistent with those caused by Rhizoctonia spp. yielded 147 Rhizoctonia isolates as determined by diagnostic characteristics of the genus, such as brown pigmented hyphae, constrictions at branch points forming right angles, absence of conidia, and presence of sclerotia in culture (9).

The samples were collected from eight Brachiaria genotypes from 10 sites (six municipalities in five departments) in Colombia representing diverse geographical zones (Tables 1 and 2; Fig. 1). They roughly separated into two groups, which were associated with differences in geographic elevation. The midelevation Popayan site, at $1,769 \mathrm{~m}$ above sea level (masl), has a mean temperature of 18 to $20^{\circ} \mathrm{C}$. Sites below 350 masl (Meta, Casanare, Cordoba, and Caqueta ) generally have mean temperatures above $25^{\circ} \mathrm{C}$. In addition to Brachiaria spp., six isolates were collected from other plant species known to be hosts of Rhizoctonia spp.: kenaf (Hibiscus cannabinus L.), sugarcane (Saccharum officinarum L.), and sorghum (Sorghum bicolor (L.) Moench).

Morphological characterization. Mycelia of all Rhizoctonia isolates cultured on PDA were white during the first 3 days of incubation. The 101 fungal isolates collected from the warmer areas of Meta, Casanare, Cordoba, and Caqueta grew faster on PDA, produced light- to dark-brown colonies, abundant brown sclerotia, and were multinucleate. These isolates were designated as type 1 isolates. The mycelia of type 1 isolates grew over the medium surface where they formed sclerotia that were initially

Table 4. Rhizoctonia isolates from Colombia used to inoculate Brachiaria cultivars to determine relative isolate virulence

\begin{tabular}{|c|c|c|c|c|}
\hline Isolate code & Location & Host & Nuclear condition & Identification $^{\mathbf{a}}$ \\
\hline $8-116(1)$ & Popayán, Cauca & Brachiaria decumbens & Binucleate & Rhizoctonia sp. AG-D \\
\hline $8-124(1)$ & Popayán, Cauca & B. brizantha & Binucleate & Rhizoctonia sp. AG-D \\
\hline $8-167(2)$ & Puerto López, Meta & Hybrid 'Mulato II' & Multinucleate & Rhizoctonia solani \\
\hline $9-193(1)$ & Florencia, Caquetá & B. decumbens & Multinucleate & R. solani \\
\hline $9-032(1)$ & Sahagún, Córdoba & B. brizantha 'Toledo' & Multinucleate & R. solani \\
\hline $9-098(2)$ & Cereté, Córdoba & B. decumbens & Multinucleate & R. solani \\
\hline $8-114(1)$ & Popayán, Cauca & B. brizantha & Binucleate & Rhizoctonia sp. AG-D \\
\hline $8-202(1)$ & Yopal, Casanare & Hybrid Mulato II & Multinucleate & R. solani \\
\hline $9-221(1)$ & Florencia, Caquetá & B. mutica & Multinucleate & R. solani \\
\hline A-36061 & Florencia, Caquetá & Hybrid 'Mulato' & Multinucleate & R. solani \\
\hline
\end{tabular}

${ }^{\mathrm{a}} \mathrm{AG}=$ anastomosis group.

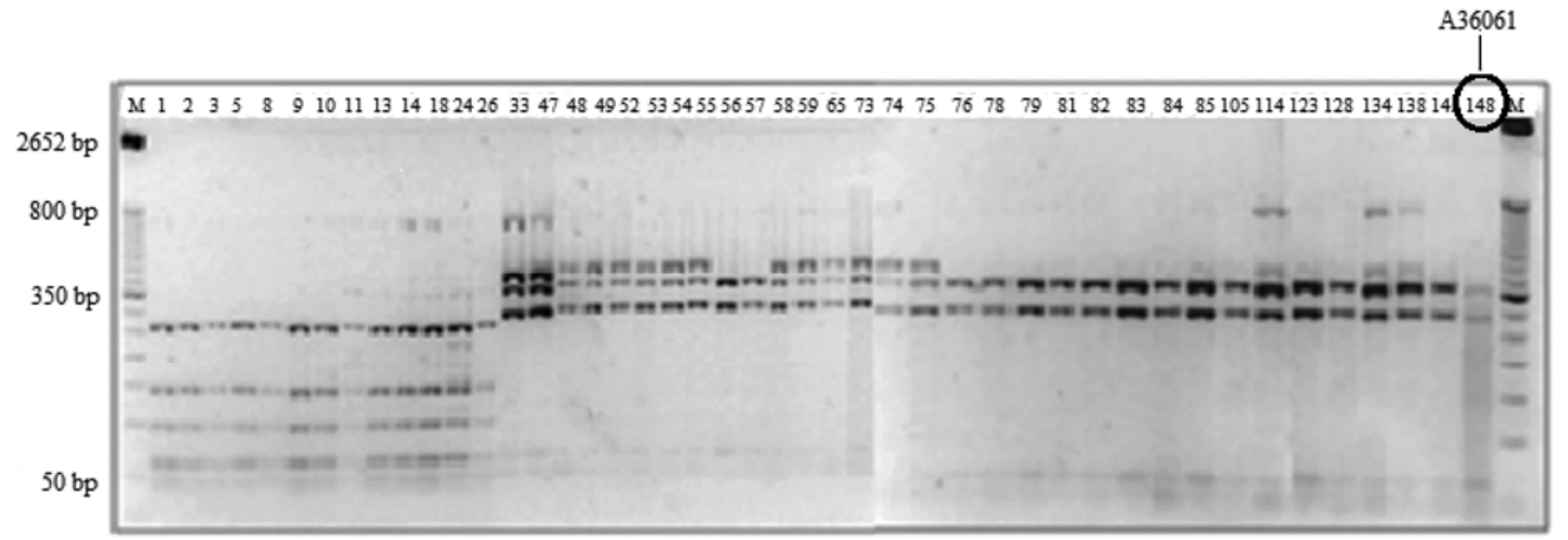

Fig. 2. Restriction fragment length polymorphism analysis of ribosomal DNA internal transcribed spacer region for Rhizoctonia isolates. Restriction patterns obtained from digestion with enzyme Taql of regions amplified from representative isolates. 
white, becoming brown. The remaining 46 isolates, designated type 2 , from the cooler Cauca area, grew more slowly and remained white on PDA, produced few or no white sclerotia, and were binucleate. The sclerotia of type 2 isolates remained white. However, the sclerotia of some isolates formed dark-brown aggregates that were 3 to $8 \mathrm{~mm}$ in diameter.

The growth rate differed among isolates according to geographic and host origins (Table 2). Isolates from Brachiaria spp. growing in the cooler site grew slowly ( 12 to $17 \mathrm{~mm} \mathrm{day}^{-1}$ ), whereas those from warmer sites grew more rapidly $\left(32\right.$ to $74 \mathrm{~mm} \mathrm{day}^{-1}$ ). The isolate from kenaf had a moderate growth rate $\left(28.5 \mathrm{~mm} \mathrm{day}^{-1}\right)$ whereas those isolates from sugarcane and sorghum grew as fast as the Brachiaria isolates obtained from warmer sites.

RFLPs and sequencing of rDNA ITS regions. The results of RFLP analysis for the 147 isolates evaluated demonstrated six different restriction patterns with enzymes EcoRI, MboI, AluI, and TaqI. The enzyme TaqI showed the highest diversity of restriction patterns. Differences in the restriction patterns obtained from PCR amplicons from isolates of Rhizoctonia with TaqI, showing two principal banding patterns, are shown in Figure 2.

A dendrogram, which includes 66 representative Rhizoctonia isolates, was obtained from a binary matrix based on the restriction patterns obtained as described above. At a Dice coefficient of 0.78 , the RFLP markers separated the Rhizoctonia isolates into two groups, which corresponded with Rhizoctonia solani AG-1 IA and Rhizoctonia sp. AG-D. There was a significant virulence difference $(P<0.0001)$ between the two groups: the $R$. solani group corresponds to highly aggressive isolates and the Rhizoctonia sp. group corresponds to less aggressive isolates (Tables 2 and 5). Using a Dice coefficient of 0.88 , the isolates clustered into five groups that represented genetic divergence within AGs. The isolates of $R$. solani AG-1 IA clustered into three subgroups and the isolates of the Rhizoctonia sp. AG-D into two subgroups. Separation at this level shows genetic divergence of the genus into subgroups. We did not find any association between RFLP diversity and geographic origin within the two groups of Rhizoctonia (Fig. 3). Sequencing of

Table 5. Analysis of variance of the area under disease progress curve of 147 Rhizoctonia isolates inoculated on Brachiaria hybrid 'Mulato' (International Center for Tropical Agriculture number 36061) for the pathogenicity study

\begin{tabular}{lrcccc}
\hline Source of variation & DF & Sum of squares & Mean square & $\boldsymbol{F}$ value & \multicolumn{2}{c}{$\boldsymbol{P r}>\boldsymbol{F}$} \\
\hline Blocks & 4 & 0.3037960 & 0.0759490 & 1.38 & 0.2411 \\
Isolates & 146 & 261.2775896 & 1.7895725 & 32.4 & $\ldots .0001$ \\
Error & 584 & 32.253527 & 0.0552285 & $\ldots$ & $\ldots$ \\
\hline
\end{tabular}

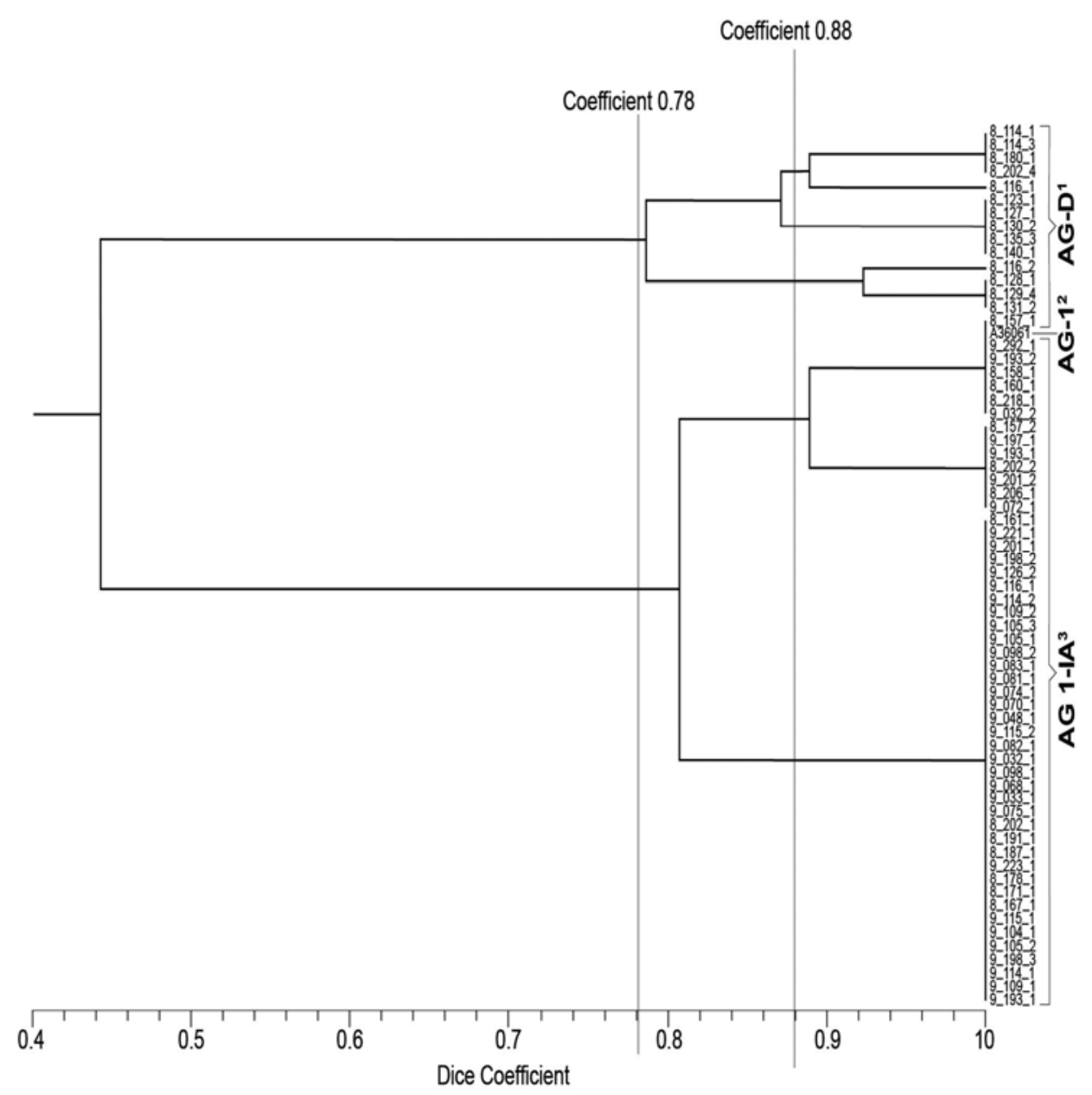

Fig. 3. Dendrogram generated from data obtained using restriction fragment length polymorphism s (RFLPs) with enzyme Taql. With a Dice coefficient of 0.75 , the RFLP molecular markers separated the Rhizoctonia isolates into two groups: Rhizoctonia solani anastomosis group (AG)-1 IA and Rhizoctonia sp. AG-D. With a Dice coefficient of 0.88 , the isolates separated into five groups that represented genetic divergence within AGs; that is, isolates of $R$. solani AG-1 IA were separated into three subgroups and isolates of the Rhizoctonia sp. AG-D into two subgroups. 1, AG-D: geographical origin, Cauca; color, white; growth rate, 14 to $17 \mathrm{~mm} /$ day; nuclear condition, binucleate; low pathogenicity. 2, AG-1 Isolate A36061. 3, AG1-IA: geographical origin, Meta, Casanare, Córdoba, and Caquetá; color, brown; growth rate, 32 to 74 mm/day; nuclear condition, multinucleate; high and intermediate pathogenicity. 
the rDNA ITS region supported the identification of the multinucleate Rhizoctonia isolates as $R$. solani of the intraspecific group I-A of AG-1 ( $R$. solani AG-1 I-A) and the identification of the binucleate Rhizoctonia isolates as AG-D (Rhizoctonia sp. AG-D). These results were obtained with a percent similarity of 97 to $99 \%$ with Rhizoctonia nucleotide sequences for ITS from GenBank. Reference accessions showing highest similarity with the sequences obtained in this study, along with the accession numbers for the sequences in this study, are presented in Table 6 .

Isolate pathogenicity. On the susceptible Mulato, under greenhouse conditions and following artificial inoculation, all isolates caused symptoms that were typical of foliar blight caused in the field by Rhizoctonia spp. However, the isolates differed in virulence, as expressed by AUDPC $(P<0.0001)$ (Table 5). The most aggressive isolates in this assay were 9-098(2), 9-111(2), 9-111(1), 9-114(1), 9-115(3), and 9-074(2) from the Department of Córdoba. These isolates are proposed as controls to be included in future studies of Rhizoctonia virulence.

The virulence of Rhizoctonia isolates in this study varied by geographic origin. The isolates (Rhizoctonia sp.) from Cauca were less aggressive than those of Meta, Casanare, Córdoba, and Caquetá ( $R$. solani). We found significant inter- and intraspecific differences among the isolates (Table 5).

Virulence study. The artificial inoculation methodology used in this study imposed a disease pressure that allowed reliable evaluation of host plant reaction and pathogen isolate virulence. Different methods, including spray and stem inoculation, were tried. Various levels and types of inoculum (Sclerotium and mycelium) were also evaluated previously to determine which produced the most reliable results (data not shown). Reliability of the methodology presented here was determined previously $(4,5)$.

Individual host plant reaction, expressed as AUDPC, to the different isolates is compared in Table 7. Significance was demonstrated for the main effects (plant genotype and fungal isolates) and their interactions. For trial 1, the relative magnitude of the $F$ value for the isolates was $95.55(\mathrm{df}=10)$, for the genotypes was 41.02 $(\mathrm{df}=9)$, and for the isolate-genotypes interaction was $3.15(\mathrm{df}=$ 90 ), with a significance of $P<0.0001$. For trial 2, the relative magnitude of the $F$ value for the isolates was $70.39(\mathrm{df}=10)$, for the genotypes was $28.03(\mathrm{df}=9)$, and for the isolate-genotype interactions was $2.90(\mathrm{df}=90)$, with a significance of $P<0.0001$. Isolates of Rhizoctonia spp. 8-116(1), 8-124(1), and 8-114(1) were the least virulent. In contrast, isolates of $R$. solani 8-202(1), 9-221(1), and A-36061 were highly virulent, behaving in a similar way in both trials.

In trial 1 , genotypes $B$. brizantha (CIAT 16320), B. humidicola (CIAT 16888), hybrid CIAT 36062, 'Marandú' (CIAT 6294), and 'Mulato II' (CIAT 36087) showed resistance to Rhizoctonia foliar blight. In trial 2, genotypes B. brizantha (CIAT 16320), Toledo (CIAT 26110), hybrid CIAT 36062, Marandú (CIAT 6294), and Mulato II (CIAT 36087) showed resistance to Rhizoctonia foliar blight (Table 7).

Isolate-genotype interactions are shown in Table 7. For isolates 8-116(1), 8-124(1), and 8-114(1) no crossover effect was observed and, as a result, these isolates ranked the genotypes the same for relative resistance. The other isolates elicited significant differ-

Table 6. Identification of Rhizoctonia isolates using comparisons of sequences of internal transcribed spacer (ITS) regions with those in the GenBank database

\begin{tabular}{lllll}
\hline $\begin{array}{l}\text { Isolate } \\
\text { code }\end{array}$ & Original location & $\begin{array}{c}\text { Accession } \\
\text { number }\end{array}$ & \multicolumn{1}{c}{ Name, similarity $\mathbf{( \% )}$} & \multicolumn{1}{c}{ Reference accession numbers } \\
\hline 8-121(2) & Popayán & JQ613580 & Rhizoctonia sp. AG-D (97) & AB198708.1, AB214367.1, AB198704.1, AB198705.1 \\
8-202(2) & Yopal, Casanare & JQ613579 & Rhizoctonia solani & AF354097.1, AY154301.1, JX089962.1, HQ270162.1, HQ185376.1 \\
$8-202(3)$ & Yopal, Casanare & JQ613578 & R. solani AG-1 IA (99) & FJ492099.3, GU570194.1, GU570187.1, FJ236314.1, HQ270162.1 \\
9-083(1) & Sahagún, Córdoba & JQ613577 & R. solani AG-1 IA (99) & FJ492099.3, GU570194.1, GU570187.1, FJ236314.1, EF429216.1 \\
9-193(1) & Caquetá & JQ613576 & R. solani AG-1 IA (99) & FJ492099.3, AY154301, JX089962.1, AF354097.1, HQ270162 \\
9-197(1) & Caquetá & JQ613575 & R. solani AG-1 IA (99) & FJ492099.3, AF354097.1, JX089962.1, AY154301.1, HQ270162.1 \\
9-292(1) & Caquetá & JQ613574 & R. solani & AY154301.1, HQ270162.1, HQ185376.1, GU570194.1, JX089962.1 \\
\hline
\end{tabular}

a Determined name and percent similarity of sequenced ITS ribosomal DNA region with GenBank database accessions; AG = anastomosis group.

Table 7. Relative virulence of different Rhizoctonia isolates inoculated on Brachiaria genotypes

Isolates $^{\mathbf{a}}$

Genotypes $^{b}$

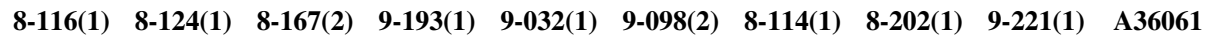

Trial 1

Brachiaria hybrid 'Mulato' (CIAT 36061)

Brachiaria hybrid 'Mulato II' (CIAT 36087)

Brachiaria decumbens 'Basilisk' (CIAT 606)

B. brizantha (CIAT 16320)

B. brizantha 'Marandú' (CIAT 6294)

B. ruziziensis (clone 44-02)

Brachiaria hybrid (CIAT 36062)

Brachiaria hybrid, clone RZ05/3394

Brachiaria hybrid, clone RZ05/3333

B. humidicola (CIAT 16888)

Trial 2

Brachiaria hybrid Mulato (CIAT 36061)

Brachiaria hybrid Mulato II (CIAT 36087)

B. decumbens Basilisk (CIAT 606)

B. brizantha (CIAT 16320)

B. brizantha Marandú (CIAT 6294)

B. ruziziensis (clone 44-02)

Brachiaria hybrid (CIAT 36062)

Brachiaria hybrid, clone RZ05/3394

Brachiaria hybrid, clone RZ05/3333

B. brizantha 'Toledo' (CIAT 26110)

\begin{tabular}{llllllllll}
12.21 & 15.06 & 21.78 & 20.10 & 23.07 & 21.48 & 10.53 & 22.62 & 26.28 & 21.93 \\
13.98 & 16.11 & 21.87 & 13.62 & 24.72 & 23.13 & 11.01 & 24.54 & 26.31 & 27.48 \\
15.21 & 15.03 & 24.33 & 20.37 & 27.30 & 22.65 & 12.60 & 26.49 & 26.70 & 24.24 \\
11.94 & 12.33 & 12.30 & 9.72 & 12.18 & 13.44 & 10.68 & 15.36 & 12.60 & 12.93 \\
15.00 & 12.66 & 24.96 & 10.74 & 17.31 & 15.03 & 11.16 & 22.89 & 20.01 & 19.59 \\
13.74 & 15.24 & 24.33 & 15.96 & 21.99 & 23.88 & 11.91 & 25.26 & 24.57 & 28.17 \\
14.61 & 15.36 & 18.98 & 11.10 & 18.00 & 20.49 & 10.38 & 18.72 & 18.90 & 15.57 \\
13.32 & 13.62 & 23.31 & 14.67 & 24.81 & 24.42 & 11.46 & 28.59 & 26.34 & 29.43 \\
13.62 & 12.93 & 24.30 & 14.34 & 27.15 & 24.21 & 12.45 & 23.88 & 25.92 & 25.80 \\
12.94 & 11.70 & 13.43 & 10.16 & 16.76 & 12.60 & 12.41 & 15.68 & 13.05 & 12.26 \\
& & & & & & & & & \\
21.60 & 19.32 & 19.68 & 16.68 & 36.33 & 26.25 & 19.71 & 34.59 & 24.03 & 28.17 \\
17.88 & 19.74 & 18.03 & 18.72 & 21.33 & 14.94 & 21.87 & 30.96 & 25.01 & 28.53 \\
22.02 & 22.56 & 29.55 & 22.47 & 31.50 & 35.50 & 22.65 & 38.85 & 38.13 & 28.65 \\
18.12 & 17.73 & 14.37 & 14.10 & 16.02 & 16.26 & 17.10 & 20.67 & 14.82 & 20.19 \\
20.16 & 20.31 & 20.94 & 21.07 & 16.08 & 17.25 & 19.26 & 26.55 & 34.83 & 19.02 \\
21.90 & 19.95 & 18.63 & 18.30 & 23.31 & 23.58 & 19.62 & 37.50 & 29.91 & 25.11 \\
18.99 & 18.62 & 16.89 & 11.26 & 24.63 & 21.84 & 21.27 & 29.46 & 17.70 & 25.05 \\
20.73 & 21.11 & 18.99 & 30.03 & 37.44 & 34.89 & 22.38 & 38.13 & 35.25 & 40.05 \\
19.83 & 21.81 & 22.14 & 33.18 & 31.71 & 23.25 & 20.79 & 36.30 & 30.45 & 31.71 \\
19.62 & 19.77 & 16.71 & 15.00 & 18.27 & 23.10 & 18.63 & 27.96 & 18.33 & 22.14 \\
\hline
\end{tabular}

${ }^{a}$ Isolate-genotype interactions are expressed as units of AUDPC. The table shows averages of untransformed data.

${ }^{\mathrm{b}}$ CIAT $=$ International Center for Tropical Agriculture. Trial 1: least significant difference $(\mathrm{LSD})$ value $=4.3$ and $P=0.05$; trial 2: LSD value $=6.6 ; P=$ 0.05 . 
ences in genotype virulence. Overall, the results showed that some Brachiaria genotypes used in the present study were resistant to Rhizoctonia foliar blight isolates analyzed in this study. A highly resistant $B$. brizantha accession, CIAT 16320, was identified in a previous study (15).

\section{Discussion}

This is the first study documenting the genetic relationships between isolates of Rhizoctonia spp. causing foliar blight in Colombia. Molecular and morphological characterization along with pathogenicity testing demonstrated that Rhizoctonia foliar blight of Brachiaria spp. was caused by more than one Rhizoctonia sp. Our data indicate that multinucleate Rhizoctonia isolates with brown colonies and fast growth were $R$. solani AG-1 IA (sexual state: Thanatephorus cucumeris), the established and predominant group causing foliar blight in the sampling locations of Colombia investigated in this study. The binucleate Rhizoctonia spp. with white, slow-growing colonies were considered to be Rhizoctonia sp. AGD (sexual state: Ceratobasidium sp.). Sequences of the rDNA ITS region also separated the groups causing foliar blight and supported their identification as $R$. solani AG-1 IA or Rhizoctonia sp. AG-D. Sequences obtained from the isolates of Rhizoctonia sp. have high similarity with those obtained and deposited in GenBank by Hayakawa et al. (11).

RFLP markers provided sufficiently high resolution to distinguish the two species of Rhizoctonia, R. solani and Rhizoctonia sp. According to Sneh et al. (23) and Vilgalys and Gonzales (28), the variability of rDNA RFLPs among isolates with the same AG shows the existence of subpopulations that differ genetically. For example, Liu and Sinclair (16) showed the existence of six intraspecific subgroups in AG-1 IA for $R$ solani. Similarly, Toda et al. (26) separated binucleate isolates of Rhizoctonia sp. AG-D into two subgroups. Improved understanding of genetic variability in the pathogen population may be useful for breeders to ensure that their work is effective with various genotypes of the pathogen in different areas. In addition, molecular markers can be used to assist the breeding process by identification of foliar blight resistance genes to be incorporated into Brachiaria cultivars.

The binucleate Rhizoctonia isolates (Ceratobasidium sp.) were only isolated from plant materials collected in the Department of Cauca at a mid-elevation site (1,760 masl), whereas the $R$. solani isolates were collected from widely dispersed lowland Colombian locations in the Departments of Meta and Casanare (Eastern Plains: Orinoco basin), Córdoba (Caribbean coastal litoral), and Caquetá (Southeast Colombia: Amazon basin). This suggests that $R$. solani is a common species, at least at warmer, lower-elevation sites: the regions where Brachiaria spp. pastures are most commonly sown in Colombia. Selection due to geographic location appears to be an important factor determining genetic structure of taxonomic groups of Rhizoctonia spp. causing foliar blight disease in Colombia.

All isolates of both species of Rhizoctonia were pathogenic to plants of Brachiaria hybrid Mulato. Pathogenicity tests on Brachiaria Mulato also revealed that isolates of $R$. solani AG-1 IA were more virulent on leaves and stems of these plants compared with Rhizoctonia sp. AG-D isolates.

The Rhizoctonia isolates from Brachiaria spp. also showed a range of virulence. Isolates of $R$. solani, 8-202(1), 9-221(1), and A36061 produced reactions of susceptibility in most of the Brachiaria materials evaluated. Therefore, they could be used as highly virulent isolates in future experiments to evaluate resistance to Rhizoctonia foliar blight.

In addition to characterization of the Rhizoctonia spp. involved in foliar blight in Colombia, this study aimed to identify potentially resistant genotypes of Brachiaria. The genotypes Brachiaria hybrid (CIAT 36062), B. brizantha Marandú (CIAT 6294), and Brachiaria hybrid Mulato II (CIAT 36087) were resistant to foliar blight in each of two screening trials. These taxa may be useful in breeding programs to increase plant resistance against this disease (Table 7). Brachiaria genotypes were chosen with general agro- nomic characteristics similar to those of commercial cultivars: improved resistance to mion spittlebug, tolerance to flooding, high seed viability, and high yield characteristics (17). Screening of additional germplasm would likely identify additional resistant Brachiaria genotypes. Further, systematic selection on the reaction to Rhizoctonia foliar blight in sexually reproducing Brachiaria breeding populations may be effective in improving the resistance currently available.

In this study, we also used isolates of Rhizoctonia collected from other crops of economic importance such as sugarcane, sorghum, and kenaf. Results suggested that these isolates were also pathogenic to Brachiaria spp., except for the isolate collected from kenaf. According to Tomaso-Peterson and Trevathan (27), pathogens isolated from one host may be pathogens of other hosts. Knowledge of the host range for Rhizoctonia AGs is fundamental for planning an integrated control system (10), thus avoiding errors that would increase inoculum and cause significant harvest losses. The information generated in this study can be helpful for planning disease management strategies and developing Brachiaria genotypes with high levels of resistance to the pathogen.

\section{Acknowledgments}

We thank C. Cardona and S. Beebe for critical review of this manuscript.

\section{Literature Cited}

1. Alvarez, E., Ospina, C. A., Mejía, J. F., and Llano, G. A. 2004. Caracterización morfológica, patogénica y genética del agente causal de la antracnosis (Colletotrichum gloeosporioides) en guanábana (Annona muricata) en el Valle del Cauca. Fitopatol. Colomb. 28:1-8.

2. Aricapa, M. G., and Correa, F. 1994. Almacenamiento de hongos en papel filtro. Ascolfi Inf. 20:29-30.

3. Bandoni, R. J. 1979. Safranin O as a rapid nuclear stain for fungi. Mycologia 71:873-874.

4. Burpee, L. L., and Goulty, L. G. 1984. Suppression of brown patch disease of creeping bent grass by isolates of nonpathogenic Rhizoctonia spp. Phytopathology 74:692-694.

5. Cardona, C., Miles, J. W., and Sotelo, G. 1999. An improved methodology for massive screening of Brachiaria spp. genotypes for resistance to Aeneolamia varia (Homoptera: Cercopidae). J. Econ. Entomol. 92:490-496.

6. Cardona, C., Miles, J. W., Zúñiga, E., and Sotelo, G. 2010. Independence of resistance in Brachiaria spp. to nymphs or to adult spittlebugs (Hemiptera: Cercopidae): implications for breeding for resistance. J. Econ. Entomol. 103:1860-1865.

7. CIAT. 2004. Pages 33-35 in: Informe Anual: 2004. Convenio Ciat-MADR, Cali, Colombia.

8. Dolores, G. H. 2002. Estado actual de la taxonomía de Rhizoctonia solani Kuhn. Rev. Mex. Fitopatol. 200:200-205.

9. González, V., Portal, M. A., and Rubio, S. 2006. Review: biology and systematics of the form genus Rhizoctonia. Span. J. Agric. Res. 4:5-79.

10. Grosh, R., Schneider, J. H. M., and Kofoet, A. 2004. Characterization of Rhizoctonia solani anastomosis groups causing bottom rot in field-grown lettuce in Germany. Eur. J. Plant Pathol. 110:53-62.

11. Hayakawa, T., Toda, T., Ping, Q., Mghalu, J. M., Yaguchi, S., and Hyakumachi, M. 2006. A new subgroup of Rhizoctonia AG-D, AG-D III, obtained from Japanese zoysia grass exhibiting symptoms of a new disease. Plant Dis. 90:1389-1394.

12. Horsfall, J. G., and Barratt, R. W. 1945. An improved grading system for measuring plant disease. (Abstr.) Phytopathology 35:655.

13. Jackson, D., Somers, K., and Harvey, H. 1989. Similarity coefficients: Measures of co-occurrence and association or simply measures of occurrence. Am. Nat. 133:436-453.

14. Jia, Y., Correa-Victoria, F., McClung, A., Zhu, L., Liu, G., Wamishe, Y., Xie, J., Marchetti, M. A., Pinson, S. R. M., Rutger, J. N., and Correll, J. C. 2007. Rapid determination of rice cultivar responses to the sheath blight pathogen using a micro chamber screening method. Plant Dis. 91:485-489.

15. Kelemu, S., Miles, J., Bonilla, X. P., and Badel, J. L. 1995. Sources of resistance in species of Brachiaria to foliar blight disease caused by Rhizoctonia solani. Trop. Grassl. 29:257-262.

16. Liu, Z. L., and Sinclair, J. B. 1993. Differentiation of intraspecific groups within anastomosis group 1 of Rhizoctonia solani using ribosomal DNA internal transcribed spacer and isozyme comparisons. Can. J. Plant Pathol. 15:272-280.

17. Miles, J., Maass, B. L., and Do Valle, C. B. 1996. Brachiaria: Biology, Agronomy, and Improvement. Centro Internacional de Agricultura Tropical (CIAT); Empresa Brasileira de Pesquisa Agropecuaria, Cali, Colombia.

18. Parmeter, J., and Whitney, H. 1970. Taxonomy and nomenclature of the perfect stage. Pages 7-19 in: Rhizoctonia solani Biology and Pathology. J. Parmeter, ed. University of California Press, Berkeley.

19. Parsons, J. J. 1972. Spread of African grasses to the American tropics. J. 
Range Manage. 25:12-17.

20. Rao, M. L., Kerridge, P. C., and Macedo, M. C. 1998. Requerimientos nutricionales y adaptación a los suelos ácidos de especies de Brachiaria. In: Brachiaria: Biology, Agronomy, and Improvement. J. W. Miles, B. L. Maass, and C. B. Valle, eds. Centro Internacional de Agricultura Tropical (CIAT); Empresa Brasileira de Pesquisa Agropecuaria, Cali, Colombia.

21. Rivas, L., and Holmann, F. 2004. Impacto de la adopción de híbridos de Brachiaria en México y Centroamérica. Working Document No. 197. Centro Internacional de Agricultura Tropical (CIAT), Cali, Colombia

22. SAS Institute Inc. 2004. What's New in SAS 9.0, 9.1, 9.1.2, and 9.1.3. SAS Institute Inc., Cary, NC.

23. Sneh, B., Burpee, L., and Ogoshi, A. 1991. Identification of Rhizoctonia species. American Phytopathology Society, St. Paul, MN.

24. Sotelo, G., Segura, G., Bonilla, J., and Miles, J. W. 2007. Develop and refine a robust, high throughput screening methodology for reaction to Rhizoctonia solani, based on greenhouse-grown plants and artificial inoculation. In: Centro Internacional de Agricultura Tropical (CIAT). 2007 Annual Report of Project IP-5-Tropical and Grasses Legumes: Optimizing Genetic Diversity for Multipurpose Use. Cali, Colombia.
25. Thomas, D., and Grof, B. 1986. Some pasture species for the tropical savannas of South America; III: Andropogonun gayanus, Brachiaria spp. and Panicum maximum, Herb. Abstr. 56:557-565.

26. Toda, T., Hyakumachi, M., Suga, H., Kageyama, K., Tanaka, A., and Tani, T. 1999. Differentiation of Rhizoctonia AG D isolates from turfgrass into subgroups I and II based on rDNA. Eur. J. Plant Pathol. 105:835-846.

27. Tomaso-Peterson, M., and Trevathan, L. E. 2007. Characterization of Rhizoctonia-like fungi isolated from agronomic crops and turfgrasses in Mississippi. Plant Dis. 91:260-265.

28. Vilgalys, R., and Gonzales, D. 1990. Ribosomal DNA restriction fragment length polymorphisms in Rhizoctonia solani. Phytopathology 80:151-158.

29. White, T. J., Bruns, T., Lee, S. B., and Taylor, J. 1990. Amplification and direct sequencing of fungal ribosomal RNA genes for philogenetics. Pages 315-322 in: PCR Protocols: A Guide to Methods and Applications. M. A Innis, D. H. Gelfand, J. J. Sninsky, and T. J. White, eds. Academic Press, New York.

30. Yang, J., and Kharbanda, P. D. 1996. Characterization, virulence, and genetic variation of Rhizoctonia solani AG 9 in Alberta. Plant Dis. 80:513 518 . 